\section{The U.S. National Academy of Sciences}

The National Academy of Sciences has recently issued a booklet reviewing the relations of the Academy with the Federal Government during its first hundred years 1863-1963 (The National Academy of Sciences, 1863-1963. Pp. 15. Washington, D.C.: National Academy of Sciences, 1963). The booklet indicates the contribution that the Academy has made to the organization of scientific departments under the United States Government, including the establishment of the National Research Council and subsequent developments during the Second World War and after.

\section{National Libraries}

UNDER the title National Libraries, the Library Association has issued a booklet containing extracts from the proceedings of the conference of the University and Research Section at Bangor in April 1963 (Pp. 56. London: The Library Association, 1963. 10s.; L.A. members, 7s. 6d.). At that conference Dr. Ib. Magnussen discussed the functions and planning of a national library, and $\mathrm{Mr}$. A. H. Chaplin introduced a discussion on a national reference and information service, in which $E . D$. Jones, S. P. L. Filon, J. A. Chaldecott and Dr. D. J. Urquhart participated. Mr. Chaplin indicated briefly the organization needed at the national level, and his plea for national support, and finance, for a co-ordinated reference and information service was warmly endorsed by Mr. Filon and Mr. Chaldecott, and to some extent by Dr. Urquhart, who emphasized that a reference service could be operated by a lending library. Dr. Magnussen distinguished seven functions of a national library and commented that the problem of centralization versus decentralization was one of the most acute and required reflexion. There was a general tendency to develop national libraries, but their relations to special fields require careful consideration and although much information service and bibliographical activity must be left to special libraries it would be injudicious and dangerous if national libraries did not consider such work. He referred particularly to the place of university libraries and urged more national planning of the library system. Dr. J. N. L. Myres, Dr. W. Beattie, Mr. E. Ansell and Mr. R. A. Wilson contributed to the discussion.

\section{Derwent Patents Manual}

THE second edition of Derwent Patents Manual (the first edition was issued in March 1962) contains briof articles on patent law and procedure in Australia, Belgium, France, Germany, India, Japan, the Netherlands, South Africa, the United Kingdom, the United States and Russia (Derwent Publications, Ltd. Derwent Patents Manual, 1964. Pp. 68. London: Derwent Publications, Ltd., 1963. 12s. 6d.; 2 dollars). There is a summary of progress with the proposal for a European patent and the Derwent International Patents Chart is also included. It is proposed to issue new editions annually in future.

\section{The British Journal for the Philosophy of Science}

The British Journal for the Philosophy of Science for November 1963 contains two articles, which, while entirely distinct, yet have a profound factor in common, namely, that of comparing present-day theoretical concepts with those set up by former generations of physicists and mathomaticians. The first, by S. J. Prokhovnik, is "The Case for an Ether", which is a hark-back to G. F. FitzGerald (not Fitzgerald, as the author writes it) and his well-known contraction. The revised version needs only a "basic inertial system", which has the æther for its space, and which need not possess the wholly abnormal properties originally ascribed to it. All it has to do is to permit isotropic electromagnetic propagation relative to it with velocity $c$. Reasons are given for supporting such a revival. The second paper is by Prof. R. I. Goodstein,
"The Significance of Incompleteness Theorems". and compares the type of incompleteness characteristic of Pappus's theorem-on account of the underivability of Desargues's perspective triangles-with that of the much more powerful theorems of Skolem and Gödel, of modern times. It is noted that, in 1934, without prior knowledge of Skolem's work, Wittgenstein must have been aware of the limitations of free variables and whole numbers. Yet, no hint of this prescience appears in the posthumous volume, Reflections on the Foundations of Mathematics.

\section{Textile Research in Poland}

Srnce 1954 the Politechnika Łódžka (Łódz Technical University) has published Scientific Bulletins (Zeszyty Naukowe) in five editions covering chemistry, food chemistry, electrical engineering, mechanical engineering, and textiles. The textiles edition (Wlokiennictwo) appears at irregular intervals approximating to one issue each year, and comprises, in the main, papers in Polish on original work carried out within the departments of the Politechnika Łódźka. Issue No. 10 (published in 1963) contains contributions from the Department of Mathematics of the Faculty of Chemistry on statistical analysis, from the Department of Bast Fibre Technology on the processing of wool fibres, and from the Department of Textile Raw Materials and Metrology on the characterization of cross-sections of man-made fibres, the quality and spinnability of wool fibres, and changes in flax, hemp and jute roving due to environmental conditions. An article on flax yarns is contributed by the Kostromskii Textile Institute of the U.S.S.R.

\section{Deterioration of Leather Fibres}

A Report, by Dr. Joane H. Bowes, entitled A Fundamental Study of the Mechanism of the Deterioration of Leather Fibres, covers a five-year study sponsored by the U.S. Department of Agriculture-Agricultural Research Service (Pp. 118. Egham, Surrey: British Leather Manufacturers' Research Association, 1963). In making leather, as in many 'traditional' industries, cmpiricism has led to diversity in the agents used to stabilize the native collagen of hides and skins. Polyphenolies, transition metal complexes and polyfunctional organic eross-linking agents may be used singly or in combination as tanning agents. Investigations into the stability of leather are therefore complicated by the many bond-types which may be present. Over the past decade there have been many publications covering specific aspects of this problem although most of them drew speculative conclusions. The present report has a much broader basis. After a preliminary study of some commercial leathers, the authors investigated the combined action of heat and moisture on collagen. From this foundation comparable studies were made on the action of heat and moisture on particular leathers, and extended to include the effects of other factors such as $p \mathbf{H}$, perspiration solutes, particularly lactates, and atmospheric oxygen. The author and her colleagues have made use of many specialist techniques, including measurements of stress-strain relationships on both intact and damaged fibres, isotope exchange studies and shrinkago temperature measurements. New methods for fractionating partially degraded proteins prior to amino-acid analysis have also boen developed. It would appear that the most important cause of deterioration of leather is a degree of moist heat sufficient to bring about hydrolytic scission of the main polypeptide chains with consequent disorganization of the molecular structure. Those tanning agents which function by introducing covalent cross-links minimize this disorganization. Relatively few of the commercially used tanning agents act in such a manner, although there is interest in glutaraldehyde -one of the materials mentioned in this report. The present work is undoubtedly a usoful foundation on which to base further developments in our undorstanding of the 